\title{
Peningkatan Hasil Belajar Keterampilan Menulis Teks Descriptive Melalui Model Kooperatif Tipe Think Talk Write (TTW) Pada Siswa Kelas X MIA 2 SMAN 2 Rambah Hilir TP 2017/2018
}

\author{
NUR IKHSAN \\ Guru SMAN 2 Rambah Hilir, Rokan Hulu \\ Email: ikhsan20@gmail.com
}

\begin{abstract}
ABSTRAK
Dengan menerapkan model pembelajaran kooperatif tipe Think Talk Write (TTW) dapat meningkatkan hasil belajar dan aktivitas belajar siswa. Model pembelajaran kooperatif TTW pada siklus 1 diperoleh hasil aktivitas siswa, untuk indikator Sangat Baik (A) persentasenya 14\%, untuk indikator Baik (B) persentasenya 44\%, untuk indikator Cukup (C) persentasenya 39\%, untuk indikator Kurang (D) persentasenya 3\% dan untuk indikator Sangat Kurang (E) persentasenya 0\%. Untuk siklus 2 diperoleh hasil aktivitas siswa, indikator Sangat Baik (A) persentasenya 28\%, untuk indikator Baik (B) persentasenya 47\%, untuk indikator Cukup (C) persentasenya 25\%, untuk indikator Kurang (D) persentasenya 0\% dan untuk indikator Sangat Kurang (E) persentasenya $0 \%$. Hal ini ditunjukkan adanya perubahan sikap siswa dalam pembelajaran, diantaranya adalah interaksi dan kerja sama antar siswa semakin baik, siswa semakin mempunyai keberanian untuk mengemukakan ide dan pendapat di depan kelas. Pusat pembelajaran tidak lagi pada guru. Siswa dituntut untuk aktif mencari informasi serta harus dapat saling bertukar pikiran. Peningkatan hasil belajar terlihat dari nilai rata-rata yang diperoleh siswa yaitu 67.50 pada siklus 1, kemudian meningkat menjadi 71,50 pada siklus 2 . Ketuntasan belajar siswa juga mengalami peningkatan pada siklus 1 adalah 77,78\%, kemudian pada siklus 2 meningkat menjadi 86,11\%. Ketuntasan belajar siswa secara klasikal sudah terpenuhi yaitu $85 \%$ dari jumlah siswa memperoleh nilai lebih besar atau sama dengan 60 .
\end{abstract}

Kata Kunci : Aktivitas Siswa, Hasil Belajar, Metode Think Talk Write (TTW),

\section{PENDAHULUAN}

Dalam pembelajaran bahasa inggris peserta didik diarahkan untuk menguasai kompetensi yang tercermin dalam kemampuan peserta didik melakukan komunikasi, baik secara lisan maupun tulisan. Sesuai dengan tujuan pengajaran bahasa Inggris tersebut, diharapkan peserta didik dapat mengembangkan potensinya sesuai dengan kemampuan, kebutuhan, dan minatnya. Selain itu, peserta didik dapat menerapkannya secara tepat dalam berkomunikasi.

Pengajaran keterampilan bahasa inggris mencakupi keterampilan mendengarkan (listening skill), keterampilan membaca (reading skill), keterampilan berbicara (speaking skill), dan keterampilan menulis (writing skill). Keempat keterampilan tersebut membentuk catur tunggal (Tarigan 1993: 1). Keempat keterampilan tersebut selalu berkaitan satu dengan yang lain. Keterampilan berbicara dan keterampilan menulis merupakan keterampilan produktif karena dapat menghasilkan suatu produk karya.

Berdasarkan pengalaman penyusun yang mengajar di SMAN 2 Rambah Hilir, khususnya di kelas X MIA 2, diketahui bahwa kondisi kemampuan menulis teks deskripsi peserta didik masih rendah. Keterampilan peserta didik dalam menulis pada mata pelajaran Bahasa Inggris, baik menulis teks descriptive, narrative, newsitem atau teks lainnya sering mengalami kesulitan, Masih banyak peserta didik yang mengalami kesulitan dalam pembelajaran menulis teks. Setiap mendapat tugas untuk menulis teks, mereka masih banyak yang belum paham bagaimana menulis teks yang benar, sehingga hasil teks peserta didik masih banyak yang salah. Adapun kekurangan tersebut disebabkan oleh 1) kurangnya 
perbendaharaan kosakata yang dikuasai peserta didik; 2) belum bisa memaksimalkan pancaindra dalam menulis teks deskripsi; 3) metode ceramah yang diterapkan oleh guru selama ini hanya memposisikan peserta didik sebagai objek belajar, bukan subjek belajar; 4) tingkat kesadaran peserta didik untuk berlatih sendiri masih jarang dilakukan.

Penyebab pertama adalah kurangnya perbendaharaan kosakata yang dikuasai peserta didik. Hal ini disebabkan oleh pengalaman dan pengetahuan peserta didik yang terbatas. Peserta didik masih kurang teliti menerapkan pengetahuan yang dimilikinya. Penyebab kedua adalah belum bisa memaksimalkan pancaindra dalam menulis teks deskripsi. Hal itu disebabkan karena pendeskripsian objek hanya seputar apa yang dilihat. Pengeksploitasian pancaindra yang lain belum dilakukan oleh peserta didik. Penyebab ketiga adalah metode ceramah yang diterapkan oleh guru selama ini hanya memposisikan peserta didik sebagai objek belajar, bukan subjek belajar. Peserta didik hanya mendengarkan penjelasan guru. Pengunaan metode ceramah menimbulkan kebosanan dan kejenuhan pada peserta didik. Peserta didik juga enggan memperhatikan penjelasan guru. Guru menjelaskan tanpa penggunaan media apapun. Penugasan diberikan dengan menyuruh peserta didik mendeskripsikan sesuatu. Hal ini membuat peserta didik hanya membayangkan objek yang hendak dideskripsikan. Dan penyebab keempat adalah tingkat kesadaran peserta didik untuk berlatih sendiri masih jarang dilakukan.

Untuk menciptakan pembelajaran yang aktif, kreatif, dan produktif, perlu menggunakan strategi, model, metode, dan teknik pembelajaran yang tepat. Dengan menggunakan strategi, model, metode, dan teknik pembelajaran yang tepat diharapkan peserta didik mampu berpikir, mengobservasi, dan menganalisis sesuai dengan kemampuan peserta didik sendiri. Peserta didik belajar bukan hanya mampu menghafal dan menirukan pendapat orang lain tetapi peserta didik diharapkan mempunyai pendapat sendiri dan pemahaman sendiri hasil dari pola penalarannya. Guru harus bisa menciptakan inovasi-inovasi dalam memberikan suatu pelajaran sehingga peserta didik memaksimalkan hasil belajar yang mereka dapat dalam dunia persekolahan. Hal tersebut menjadi tantangan dan pekerjaan rumah bagi guru dan orang-orang yang terlibat secara tidak langsung dalam meningkatkan mutu pendidikan Indonesia.

Berdasarkan kendala yang dihadapi penyusun tersebut di atas, maka melalui rencana penelitian tindakan kelas ini peneliti akan mencoba menggunakan metode pembelajaran model kooperatif tipe Think Talk Write untuk mengembangkan keterampilan pembelajaran menulis. Model pembelajaran ini digunakan untuk membantu peserta didik agar lebih aktif dan produktif. Model pembelajaran kooperatif tipe Think Talk Write merupakan sebuah model pembelajaran yang dapat dijadikan sebuah alternatif.

Model kooperatif tipe Think Talk Write merupakan suatu model yang mengutamakan adanya kerjasama, yakni kerjasama antar peserta didik dalam kelompok untuk mencapai tujuan pembelajaran. Dalam pembelajaran kooperatif tipe Think Talk Write peserta didik dituntut untuk mengeluarkan ide yang dimilikinya untuk kemudian membaginya dengan teman sekelompok untuk saling mendapat masukan dan motivasi. Peserta didik yang sebelumnya terbiasa bersikap pasif setelah menggunakan model pembelajaran berkelompok ini akan terpaksa berpartisipasi secara aktif agar bisa diterima oleh anggota kelompoknya (Adriani. 2008: 189). Model pembelajaran kooperatif tipe Think Talk Write tidak sama dengan sekadar belajar dalam kelompok. Ada unsur- unsur dasar pembelajaran model kooperatif tipe Think Talk Write yang membedakan dengan pembagian kelompok yang dilakukan asalasalan. Pelaksanaan prosedur model kooperatif tipe Think Talk Write dengan benar akan memungkinkan pendidik mengelola kelas dengan lebih efektif.

TINJAUAN PUSTAKA

Hakikat Model Pembelajaran Kooperatif Tipe Think Talk Write (TTW)

Model pembelajaran kooperatif merupakan salah satu model pembelajaran yang 
mendukung pembelajaran kontekstual. Sistem pembelajaran kooperatif dapat didefinisikan sebagai sistem kerja/ belajar kelompok yang terstruktur. Yang termasuk di dalam struktur ini adalah lima unsur pokok (Johnson \& Johnson, 1993), yaitu saling ketergantungan positif, tanggung jawab individual, interaksi personal, keahlian bekerja sama, dan proses kelompok. Menurut Arends (2008: 37), akar intelektual pembelajaran kooperatif berasal dari tradisi pendidikan yang menekankan pemikiran dan praktis demokratis: belajar secara aktif, perilaku kooperatif, dan menghormati pluralisme di masyarakat yang multikultural.

Tujuan pembelajaran kooperatif berbeda dengan kelompok konvensional yang menerapkan sistem kompetisi, di mana keberhasilan individu diorientasikan pada kegagalan orang lain, sedangkan tujuan dari pembelajaran kooperatif adalah menciptakan situasi di mana keberhasilan individu ditentukan atau dipengaruhi oleh keberhasilan kelompoknya (Slavin, 2005).

Model pembelajaran kooperatif dikembangkan untuk mencapai setidak- tidaknya tiga tujuan pembelajaran penting yang dirangkum oleh Ibrahim (2000), yaitu:

\section{Hasil Belajar Akademik}

Dalam belajar kooperatif meskipun mencakup beragam tujuan sosial, juga memperbaiki prestasi peserta didik atau tugas-tugas akademis penting lainnya. Beberapa ahli berpendapat bahwa model ini unggul dalam membantu peserta didik memahami konsep-konsep sulit. Para pengembang model ini telah menunjukkan bahwa model struktur penghargaan kooperatif telah dapat meningkatkan nilai peserta didik pada belajar akademik dan perubahan norma yang berhubungan dengan hasil belajar. Di samping mengubah norma yang berhubungan dengan hasil belajar, pembelajaran kooperatif dapat memberi keuntungan baik pada peserta didik kelompok bawah maupun kelompok atas yang bekerja bersama menyelesaikan tugastugas akademik.

\section{Penerimaan Terhadap Perbedaan Individu}

Tujuan lain model pembelajaran kooperatif adalah penerimaan secara luas dari orang-orang yang berbeda berdasarkan ras, budaya, kelas sosial, kemampuan, dan ketidakmampuannya.
Pembelajaran kooperatif memberi peluang bagi peserta didik dari berbagai latar belakang dan kondisi untuk bekerja dengan saling bergantung pada tugas-tugas akademik dan melalui struktur penghargaan kooperatif akan belajar saling menghargai satu sama lain.

\section{Pengembangan Keterampilan Sosial}

Tujuan penting ketiga pembelajaran kooperatif adalah mengajarkan kepada peserta didik keterampilan bekerjasama dan kolaborasi. Keterampilan- keterampilan sosial, penting dimiliki oleh peserta didik sebab saat ini banyak anak muda masih kurang dalam keterampilan sosial.

Pembelajaran kooperatif adalah suatu sistem yang di dalamnya terdapat elemen-elemen yang saling berhubungan. Elemen-elemen yang sekaligus merupakan karakteristik pembelajaran kooperatif adalah sebagai berikut: saling ketergantungan positif, interaksi tatap muka, akuntabilitas individual, dan keterampilan hubungan antar pribadi (Nurhadi dan Senduk, 2003: 60). Berikut penjelasan untuk masing-masing elemen.

\section{METODOLOGI PENELITIAN}

\section{Tempat dan Waktu Penelitian}

Penelitian tindakan kelas ini dilaksanakan di kelas X Mia 2 SMAN 2 Rambah Hilir Semester Ganjil Tahun Pelajaran 2017/2018, yang akan berlangsung selama satu bulan yaitu bulan Oktober sebanyak 4 kali pertemuan yang dibagi menjadi 2 siklus. Siklus I terdiri dari 2 kali pertemuan dan siklus II sebanyak 2 kali pertemuan juga. Jumlah pelajaran bahasa inggris dalam satu minggu adalah 2 jam pelajaran dimana satu jam pelajaran waktunya 45 menit.

\section{Subjek Penelitian}

Dalam penelitian ini subyek penelitiannya adalah seluruh siswa kelas X Mia 2 SMAN 2 Rambah Hilir, yang berjumlah 36 siswa, yang terdiri dari 27 siswa perempuan dan 9 siswa laki-laki.

\section{Prosedur Penelitian}

Penelitian tindakan kelas ini dilaksanakan dalam bentuk proses pengkajian bersiklus yang terdiri dari 4 tahapan. Tahapan tersebut adalah perencanaan, tindakan, observasi, dan refleksi. 


\section{Perencanaan (Planning)}

Pada tahap ini dilakukan penyusunan rencana kegiatan dengan menentukan langkah-langkah yang dilakukan peneliti untuk memecahkan masalah. Masalah yang dialami dalam pembelajaran menulis teks descriptive selama ini adalah masih rendahnya keterampilan peserta didik dalam menulis teks descriptive karena model pembelajaran dan media yang digunakan kurang inovatif, kurang bervariasi dan kurang sesuai dengan karakteristik peserta didik. Upaya untuk mengatasi masalah tersebut adalah dengan menerapkan model pembelajaran dan menggunakan media pembelajaran yang lebih bervariasi dan sesuai dengan kompetensi dasar yang akan dicapai, yaitu model pembelajaran kooperatif tipe TTW (Think Talk Write).

Dalam tahap ini, peneliti mempersiapkan proses pembelajaran keterampilan menulis teks descriptive dengan langkah- langkah: (1) menyusun rencana pembelajaran yang berhubungan dengan keterampilan menulis teks descriptive; (2) menyiapkan media gambar yang akan digunakan sebagai media pembelajaran; (3) menyusun instrumen tes dan nontes. Instrumen yaitu soal uraian beserta penilaiannya, sedangkan instrumen nontes berupa lembar observasi,.

Peserta didik direncanakan menulis dalam kelompok berlima menggunakan gambar tempat bersejarah. Siklus pertama diselesaikan dalam 2 pertemuan.

\section{Tindakan (Action)}

Tindakan yang dilakukan peneliti dalam meneliti proses pembelajaran menulis descriptive pada siklus I ini sesuai dengan perencanaan yang telah disusun secara matang. Tindakan yang dilakukan peneliti secara garis besar adalah melaksanakan proses pembelajaran menulis teks descripsi melalui model kooperatif tipe Think Talk Write dengan media gambar. Tindakan ini dilaksanakan dalam tiga tahap pada masing-masing siklus, yaitu tahap pendahuluan, tahap inti, dan tahap penutup. Tindakan pada masing-masing tahap dijabarkan sebagai berikut.

Pada tahap pendahuluan dilaksanakan langkah-langkah sebagai berikut:

(1) Guru mengondisikan peserta didik untuk siap mengikuti pembelajaran hari ini dengan mempresensi peserta didik ;

(2) Guru mengatur kondisi kelas yang kondusif, dan menjelaskan tujuan pembelajaran, yaitu peserta didik dapat menulis teks descriptive secara singkat, padat dan jelas;

(3) Guru bertanya kepada peserta didik tentang kesulitan menulis teks descriptive pada pertemuan prasiklus.

Pada tahap inti pembelajaran dilakukan dengan langkah-langkah:

(1) Guru memberikan sebuah gambar beserta teks descriptive kepada peserta didik;

(2) Peserta didik menemukan pokokpokok atau unsur dalam teks descriptive;

(3) Peserta didik mendengarkan penjelasan guru tentang langkahlangkah pembelajaran kooperatif tipe Think Talk Write (TTW)

(4) Peserta didik membentuk kelompok (setiap kelompok beranggotakan 5-6 peserta didik);

(5) Masing-masing kelompok mendapat gambar yang berbeda.

(6) Setiap anggota kelompok mengamati gambar dengan teliti (bila perlu menuliskan informasi yang penting);

(7) Peserta didik berdiskusi dengan teman sekelompok mengenai gambar yang telah dibagikan, untuk mendapat masukan dan motivasi (mengenai unsur-unsur teks descriptive);

(8) Guru mengamati pekerjaan peserta didik sambil mencatat hal-hal yang penting dan memberikan penjelasan

(9) Peserta didik mulai menulis teks descriptive secara individu berdasarkan gambar yang telah diamati dan hasil diskusi dengan teman sekelompoknya

(10) Peserta didik saling menukarkan hasil tulisannya dengan teman sekelompok dan memilih teks descriptive terbaik;

(11) Perwakilan kelompok membacakan teks descriptive yang terbaik dalam kelompoknya dan kelompok lain memberi komentar. 
Pada tahap penutup,

Peserta didik dan guru mengadakan refleksi terhadap kegiatan pembelajaran pada hari. Dengan refleksi tersebut dapat diketahui tanggapan peserta didik mengenai proses pembelajaran yang telah dilaksanakan pada hari itu sebagai perenungan agar materi benarbenar dipahami oleh peserta didik.

Pengamatan (Observation)

Selama kegiatan ini guru mengamati peserta didik dan mencatatnya. Pengamatan bisa meliputi sikap dan perilaku peserta didik, baik yang dikehendaki seperti ; menuliskan frase benda, kalimat dan paragraph dengan benar untuk mendeskripsikan gambar, maupun yang tidak dikehendaki (Off Task), seperti mengobrol, mengganggu teman, bergerak ke arah yang tidak semestinya, berdiri dan duduk terlalu sering pada saat pembelajaran, keluar/masuk kelas, mengantuk, melamun, bermain HP/benda lain, mengerjakan tugas pelajaran lain, dan lain-lain. Selain itu juga diadakan penilaian terhadap tulisan peserta didik. Dari hasil pengamatan digunakan untuk menentukan apakah tindakan bisa dihentikan atau perlu dilanjutkan.

\section{Refleksi (Reflexion)}

Pada tahap ini peserta didik diajak berdiskusi apakah mereka menyukai strategi pembelajaran tersebut. Apabila peserta didik masih merasa belum menyukai, atau peserta didik masih belum berhasil belajar aktif dalam pembelajaran, maka perlu ditanyakan apa yang menjadi kendala mereka. Peserta didik juga tahu apa yang seharusnya dan tidak seharusnya dilakukan selama pembelajaran. Pada tahap ini juga dilakukan untuk mengoreksi apa yang telah dilakukan oleh guru selama tindakan, apakah sudah sesuai dengan rencana atau belum, apakah guru cukup memberikan bantuan kepada peserta didik, serta memberikan motivasi pada peserta didik yang kurang aktif. Refleksi dalam penelitian tindakan kelas sekaligus merupakan analisis data.

\section{HASIL PENELITIAN DAN PEMBAHASAN \\ Hasil Penelitian}

Hasil pelaksanaan tindakan pada siklus 1 dan 2 menunjukkan bahwa penerapan model pembelajaran kooperatif TTW (Think-TalkWrite) dapat meningkatkan hasil belajar belajar siswa pada keterampilan menulis teks descriptive. Peningkatan Hasil belajar dan ketuntasan belajar siswa dapat dilihat pada grafik sebagai berikut:

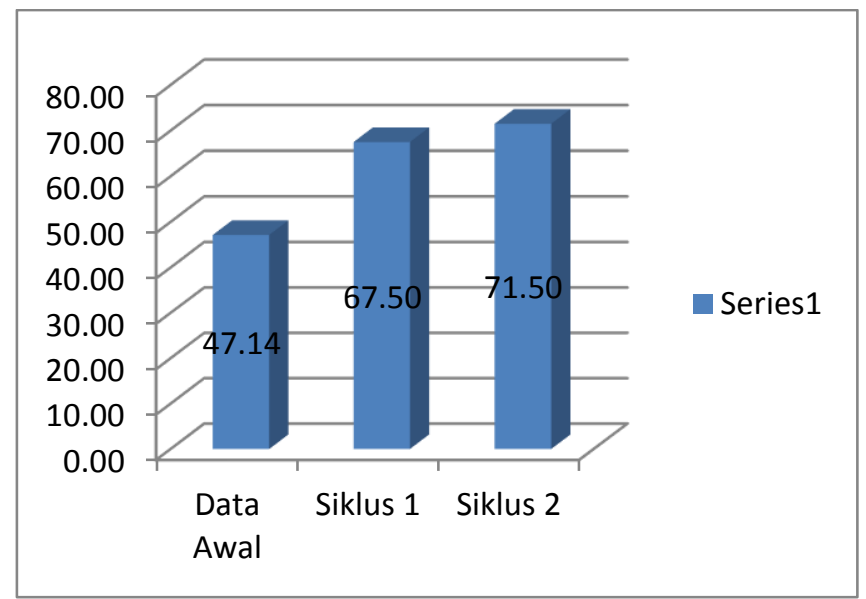

Gambar. Diagram peningkatan hasil belajar siswa 


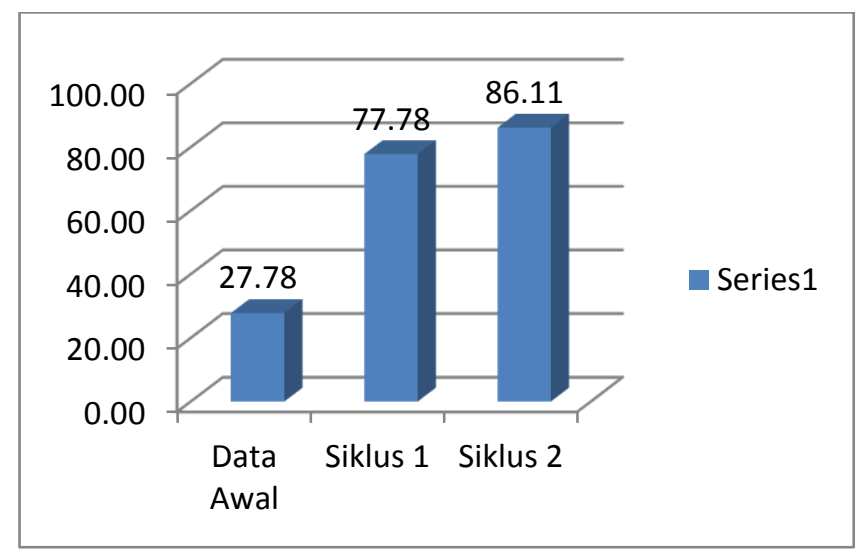

Gambar. Diagram ketuntasan belajar siswa

Dari diagram tersebut memberikan informasi bahwa pada nilai rata-rata kelas mengalami peningkatan. Sebelum adanya penerapan model pembelajaran kooperatif TTW nilai rata-rata kelas siswa adalah 47,14 tetapi setelah penerapan model pembelajaran kooperatif TTW nilai rata-rata kelas siswa menjadi 67,50 pada siklus 1 dan 71,50 pada siklus 2. Terjadi peningkatan nilai rata-rata siswa dibandingkan sebelum diterapkannya model pembelajaran TTW. Sebanyak 28 siswa $(77,78 \%)$ mendapatkan nilai di atas 60 dan pada siklus 2 nilai rata-rata kelas 71,50 sehingga terjadi peningkatan dibanding siklus 1 . Sebanyak 31 siswa $(86,11 \%)$ sudah mencapai nilai di atas 60 dari $75 \%$ target yang direncanakan. Hasil penelitian ini mendukung hasil penelitian yang sebelumnya yang dilaksanakan oleh Imama Wahidah, Ipung Yuwono yang berjudul "Penerapan Strategi Think Talk Write (TTW) untuk Meningkatkan Hasil Belajar Matematika Siswa Kelas VII SMP Brawijaya Smart School (BSS)". Penelitian tersebut menyimpulkan bahwa peningkatan hasil tes siswa yang ketuntasan klasikalnya lebih dari $80 \%$ dan skor aktivitas guru dan aktivitas siswa termasuk lebih dari kategori BAIK.

Aktivitas siswa pada siklus 1 meningkat ratarata dengan kategori Sangat Baik ( A ) persentasenya 14\%, untuk kategori Baik ( B ) persentasenya 44\%, untuk kategori Cukup ( C ) persentasenya $39 \%$, untuk kategori Kurang ( D ) persentasenya 3\% dan untuk kategori Sangat Kurang ( E ) persentasenya 0\%. Sedangkan pada siklus 2 diperoleh hasil, kategori Sangat Baik (A) persentasenya $28 \%$, untuk kategori Baik ( B ) persentasenya 47\%, untuk kategori Cukup ( C ) persentasenya 25\%, untuk kategori
Kurang ( D ) persentasenya 0\% dan untuk kategori Sangat Kurang (E ) persentasenya 0\%. Dari 2 siklus terjadi peningkatan aktivitas siswa dengan menerapkan model pembelajaran kooperatif tipe TTW meningkat secara signifikan.

Penerapan model pembelajaran kooperatif Think Talk Write (TTW) pada siklus 1 berjalan cukup lancar, siswa pun dapat ikut berpartisipasi di dalam KBM meskipun ada beberapa siswa yang mengganggu peserta didik lainnya dan kurang memperhatikan. Berdasarkan hasil pengamatan terhadap proses belajar mengajar pada siklus 1 masih terdapat kekurangan yaitu siswa belum bisa bekerja sama secara optimal dengan teman sebangkunya. Selain itu, siswa juga belum berani untuk mengemukakan pendapatnya di depan teman-teman dan guru. Hasil belajar siswa pada siklus 1 juga masih rendah meskipun sudah ada beberapa siswa yang mendapatkan nilai di atas 60. Peneliti mencari solusi dengan merencanakan siklus 2. Materi pada siklus 2 adalah objek wisata. Berdasarkan hasil pengamatan terhadap proses pembelajaran pada siklus 2 siswa terlihat semakin aktif dan kelemahan pada siklus 1 sudah teratasi pada siklus 2. Siswa yang sebelumnya masih kurang aktif dalam pembelajaran sekarang mulai berani bertanya dan memberikan pendapatnya kepada teman ataupun guru.

Berdasarkan uraian di atas dapat disimpulkan bahwa Penelitian Tindakan Kelas (PTK) upaya peningkatan aktivitas dan hasil belajar pada keterampilan menulis teks descriptive melalui model pembelajaran kooperatif Think Talk Write (TTW) bagi siswa kelas X Mia 2 SMA N 2 Rambah Hilir Tahun Pelajaran 2017/2018 
adalah berhasil dan dapat dipertanggungjawabkan hasilnya. Hal ini dikarenakan PTK telah dilaksanakan sesuai dengan prosedur penelitian mulai dari tahap perencanaan, pelaksanaan tindakan, observasi, dan refleksi.

\section{Kesimpulan}

Berdasarkan hasil penelitian dan pembahasan yang telah diuraikan, dapat diambil simpulan sebagai berikut:

Dengan menggunakan model pembelajaran kooperatif tipe TTW dapat meningkatkan aktivitas dan hasil belajar pelajaran bahasa inggris pada keterampilan menulis teks descriptive pada siswa kelas X Mia 2 semester ganjil SMA Negeri 2 Rambah Hilir Tahun ajaran 2017/2018. Hal ini ditunjukkan adanya perubahan sikap siswa dalam pembelajaran, diantaranya adalah interaksi dan kerja sama antar siswa semakin baik, siswa semakin mempunyai keberanian untuk mengemukakan ide dan pendapat di depan kelas serta pusat pembelajaran tidak lagi pada guru. Siswa dituntut untuk aktif mencari informasi serta harus dapat saling bertukar pikiran.

Peningkatan ini terlihat dari nilai rata-rata yang diperoleh siswa yaitu 67.50 pada siklus 1 , kemudian meningkat menjadi 71,50 pada siklus 2. Ketuntasan belajar siswa juga mengalami peningkatan pada siklus 1 adalah $77,78 \%$, kemudian pada siklus 2 meningkat menjadi $86,11 \%$. Ketuntasan belajar siswa secara klasikal sudah terpenuhi yaitu $85 \%$ dari jumlah siswa memperoleh nilai lebih besar atau sama dengan 60. Namun secara individual masih ada 5 siswa yang belum tuntas belajar. Siswa mempunyai kesempatan untuk mempelajari materi secara berulang-ulang dan kemudahan memahami materi yang disampaikan oleh teman sebaya. Siswa dituntut untuk bertukar informasi atau mengajarkan materi kepada temannya sehingga dapat meningkatkan pemahaman dan ingatan siswa pada materi yang dipelajari.

\section{DAFTAR PUSTAKA}

Andriani, M. 2008. Strategi Pembelajaran Think Talk Write. [Online]. Tersedia: http://mellyirzal.blogspot.com/2008/12/strat egi-pembelajaran-think-talk-write.html.

Diakses pada tanggal 28 Desember 2017

Ansari. 2003. Ebookbrowse.

http://ebookbrowse.com/modelpembelajaran -menulis-dengan-teknik-think-pdf-d32454.

Diakses pada tanggal 2 Januari 2017.

Anwar, Rosihan. 2004. Bahasa Jurnalistik Indonesia dan Komposisi. Yogyakarta: Media Abadi.

Arends, Richard I. 2008. Classroom Instrument and Management. USA: The Mc.Graw-Hill Companies.

Haryuniasih, Dwi Wuryatni. 2009. Peningkatan Keterampilan Menulis Deskripsi Melalui Pemanfaatan Media Pembelajaran Realia pada siswa Kelas XI TKJ-2 SMKN 1 Slawi Tahun Pelajaran 2008/2009. Didaktika Jurnal Kependidikan I : 554-568. Semarang: Dinas Pendidikan Provinsi Jawa Tengah.

Ibrahim dan Nana Syaodih. 2000. Perencanaan Pengajaran. Jakarta: Asdi Mahasatya.

Jhonson, D.W., \& Jhonson, R. 1994. Learning Together And Alone: Cooperative, Competitive, and individualistic, Englewood Cliff N.J,: Prentice Hall, inc. (terjemahan ebookbrowse http://ebookbrowse.com diunduh pada 4 Desember 2017.

Hartono, Bambang. 2000. Kajian Wacana Bahasa Indonesia. Semarang: FBS. UNES.

Kridalaksana, Harimukti. 2005. Kamus Linguistik. Jakarta: PT Gramedia Pustaka Utama.

Nuraini, Umri dan Indriani. 2008. Bahasa Indonesia untuk Sekolah Dasar Kelas V. Jakarta: Pusat Perbukuan Departemen Pendidikan Nasional.

Nurhadi dan Senduk, Agus Gerrard. 2003. Pembelajaran Kontekstual dan Penerapannya dalam KBK. Malang: Penerbit Universitas Negeri Malang.

Semi, M. Atar. 1990. Menulis Efektif. Padang: Angkasa Raya.

Silberman, M. 2001. Active Learning: 101 Strategi Pembelajaran Aktif. Yogyakarta: Yapendis.

Slavin, Robert E. 2005. Cooperative Lerning. Bandung: Nusa Media.

Sudarwati. Th.M dan Eudia Grace. 2005. Look ahead X: an English Course for Senior 
High School Students Year X. Jakarta: Erlangga

Sudiati, Verro. 2005. Kiat Menulis Deskripsi dan Narasi. Yogyakarta: Pustaka Widyatama.

Suparno, Muhammad dan Yunus. 2007. Keterampilan Dasar Menulis. Jakarta: Universitas Terbuka.

Tarigan, Henry Guntur. 1993. Menulis Sebagai Suatu Keterampilan Berbahasa. Bandung: Angkasa.

Wijaya, Cece. 2007. Pendidikan Remedial Sarana Pengembangan Mutu Sumber Daya Manusia. Bandung: PT Remaja Rosdakarya.

Wiyanto, Asul. 2004. Terampil Menulis Paragraf. Jakarta: Gramedia Widiasarana Indonesia.

Yamin, M. 2008. Taktik Mengembangkan Kemampuan Individual Siswa. Jakarta : Gaung Persada Press.
Subyakto, dkk. 2004. Materi Pelatihan Terintegrasi 3 "Bahasa Indonesia". Jakarta: Departemen Pendidikan Nasional, Direktorat Pendidikan Lanjutan Pertama.

Suhendar M.E, Supinah Pien. 1993. Efektifitas Metode Pengajaran Bahasa Indonesia. Bandung: Pionir Jaya.

Suyatno. 2004. Teknik Pembelajaran Bahasa dan Sastra. Surabaya:SIC

Wagiran, Doyin Mukh. 2005. Curah Gagasan Pengantar Penulisan Karya Ilmiah. Semarang: Rumah Indonesia.

Wirodijoyo, Suwaryono. 1989. Membaca: Strategi Pengantar dan Tekniknya. Jakarta: Departemen Pendidikan dan Kebudayaan Direktorat Jendral Pendidikan Tinggi Proyek Pengembangan Lembaga Pendidikan Tenaga Kependidikan. 